\title{
PERTUMBUHAN DAN KARAKTERISTIK MORFOLOGI RUMPUT (Ischaemum $s p$ ) TANAH ASAL AMBAN DAN KEBAR DENGAN LEVEL DOSIS PUPUK NPK YANG BERBEDA
}

\author{
Onesimus Yoku, Daniel Yohanis Seseray dan Maria Krey \\ Fakultas Peternakan Universitas Papua \\ Email: varol.seseray@gmail.com
}

\begin{abstract}
ABSTRAK
Pakan hijauan merupakan pakan basal ternak ruminansia, sehingga ketersediaannya baik kualitas, kuantitas maupun kontinuitasnya merupakan faktor yang penting dalam menentukan keberhasilan usaha peternakan ternak ruminansia. Penelitian ini bertujuan untuk mengetahui pengaruh tanah asal Amban dan Kebar dengan level dosis pupuk NPK terhadap karakteristik morfologi rumput Ischaemum sp, yang meliputi karakteristik daun (panjang daun, lebar daun), dan batang (panjang ruas, diameter batang) serta produktivitas rumput Ischaemum sp yaitu tinggi tanaman, jumlah anakan dan jumlah daun. Metode yang digunakan pada penelitian ini yaitu rancangan acak lengkap (RAL) pola faktorial. Faktor pertama adalah asal tanah dengan 2 (dua) taraf dan faktor kedua adalah dosis pupuk NPK dengan 3 (tiga) taraf. Data yang diperoleh diolah menggunakan metode eksperimen dalam rancangan acak lengkap (RAL) pola faktorial, apabila berpengaruh signifikan akan diuji lanjut dengan Beda Nyata Jujur (BNJ). Hasil penelitian menunjukkan bahwa pemberian perlakuan tanah asal Amban dan Kebar dengan dosis pupuk o NPK, o,165 NPK dan 0,330 NPK tidak memberikan pengaruh yang signifikan terdahap pertumbuhan tinggi tanaman, jumlah anakan dan jumlah daun serta karakteristik daun (panjang dan lebar daun), batang (panjang ruas dan diameter batang). Rata-rata pertumbuhan tinggi dan laju pertumbuhan, serta jumlah anakan dan jumlah daun tanaman rumput Ischaemum sp pada tanah Kebar lebih tinggi dibandingkan tanah asal Amban. Karakteristik daun dan batang rumput Ischaemum sp pada 2 MSP hingga 6 MSP ukuran maksimal panjang daun $36,2 \mathrm{~cm}$; lebar daun 1,7; panjang ruas $7,5 \mathrm{~cm}$ dan diameter batang $0,3 \mathrm{~mm}$.
\end{abstract}

Kata kunci: tanah, pupuk, morfologi, karakteristik, rumput Ischaemum sp

\section{PENDAHULUAN}

Pakan hijauan merupakan pakan basal ternak ruminansia, sehingga ketersediaannya baik kualitas, kuantitas maupun kontinuitasnya merupakan faktor yang penting dalam menentukan keberhasilan usaha peternakan ternak ruminansia. Hal ini disebabkan hampir 90\% pakan ternak ruminansia berasal dari hijauan dengan konsumsi perhari sekitar $10-15 \%$ dari berat badan, sedangkan sisanya adalah konsentrat dan pakan tambahan lainnya (feed supplement) (Sirait et al., 2005). Peluang pengembangan sapi potong di Papua Barat terbuka luas dengan membangun pusat bibit sapi (breeding centre) salah satunya di Kebar yang memiliki luas lahan rumput mencapai 1.500 hektar dengan proyeksi populasi 1.875 ekor (Woran dan Sumpe, 2007). Selain itu lembah Kebarjuga memiliki jenis rumput padangan yang dapat dikembangkan sebagai sumber pakan ternak. Salah satu jenis rumput padangan yang cukup potensial sebagai pakan ternak adalah jenis rumput padangan (Ischaemum $s p$ ).

Menurut Sajimin et al. (2001), untuk memperoleh produksi yang tinggi pada lahan yang tingkat kesuburannya rendah dapat dilakukan dengan penggunaan pupuk organik. Penyediaan unsur hara terutama nitrogen $(\mathrm{N})$, phosphor $(\mathrm{P})$, dan kalium (K) dalam tanah secara optimal bagi tanaman dapat meningkatkan produktivitas tanaman.

Kurangnya informasi mengenai jenis rumput padangan (Ischaemum sp) yang ada di Lembah Kebar dan upaya pengembangan menjadi rumput budidaya, maka perlu dilakukan penelitian mengenai klasifikasi morfologi rumput Ischaemum sp pada media tanam yang berbeda serta pemberian pupuk NPK.

Penelitian ini bertujuan untuk mengetahui pengaruh tanah asal Amban dan Kebar dengan level dosis pupuk NPK yang berbeda terhadap tinggi tanaman, jumlah anakan dan jumlah daun serta karakteristik morfologi rumput Ischaemum sp, yang meliputi karakteristik daun (panjang daun, lebar daun), dan batang (panjang ruas, diameter batang). Diharapkan penelitian ini dapat dijadikan informasi awal dalam perngembangan rumput Ischaemum $s p$. 


\section{MATERI DAN METODE}

\section{Tempat dan Waktu Penelitian}

Penelitian dilaksanakan di Kompleks Perumahan Dosen Universitas Papua (UNIPA),

Amban, Manokwari. Sedangkan analisis kimia dan fisik tanah dilakukan di Lab. Tanah, Fakultas Pertanian dan Teknologi Pertanian UNIPA, Manokwari. Penelitian ini dilaksanakan selama 4 (empat) bulan.

\section{Bahan dan Alat}

Bahan yang digunakan dalam penelitian ini meliputi, tanah asal Amban dan Kebar, bibit rumput dari lembah Kebar, pupuk NPK, dan air. Sedangkan alat yang digunakanan adalah timbangan digital merk Acis dengan ketelitian 0,01, pacul, sekop, parang, arit, timbangan, gunting stek, mistar/meteran, jangka sorong (caliper), kamera digital, ember, kalkulator, karung, polibag dan alat tulis menulis.

\section{Metode}

Metode yang digunakan pada penelitian ini yaitu rancangan acak lengkap (RAL) pola faktorial. Faktor pertama adalah asal tanah dengan 2 (dua) taraf dan faktor kedua adalah dosis pupuk NPK dengan 3 (tiga) taraf. Semua kombinasi perlakuan diulang sebanyak 10 kali.

Perlakuan dua asal tanah yaitu tanah asal Amban (A) dan tanah asal Kebar (K) sebagai faktor pertama dan perlakuan pupuk NPK masing-masing tanpa pupuk (o NPK); 0,165 g N/pot (o,165 NPK); dan o,330 g N/pot (o,330 NPK) sebagai faktor kedua. Jadi rancangan percobaannya adalah RAL faktorial 2 $\times 3 \times 1$, sehingga jumlah satuan percobaannya adalah 60 satuan percobaan. Notasi atau kode perlakuan disajikan pada Tabel 1.

Tabel 1. Notasi Perlakuan Asal Tanah dan Pupuk NPK

\begin{tabular}{cccc}
\hline \multirow{2}{*}{ Faktor Pertama } & \multicolumn{3}{c}{ Faktor Kedua } \\
\cline { 2 - 4 } Amban & 0 NPK & 0,165 NPK & 0,330 NPK \\
\hline \multirow{2}{*}{ Kebar } & A0 NPK & A0,165 NPK & A0,330 NPK \\
& A01 s/s A10 & A11 s/d A20 & A21 s/d A30 \\
& K0 NPK & K0,165 NPK & K0,330 NPK \\
& K01 s/s K10 & K11 s/d K20 & K21 s/d K30
\end{tabular}

Keterangan:

A01 s/d A10 = Perlakuan tanah Amban dan $0 \mathrm{~g}$ NPK, untuk ulangan $1 \mathrm{~s} / \mathrm{d} 10$ K01 s/d K10 = Perlakuan tanah Kebar dan $0 \mathrm{~g}$ NPK, untuk ulangan $1 \mathrm{~s} / \mathrm{d} 10$ A11 s/d A20 = Perlakuan tanah Amban dan 0,165 g NPK, untuk ulangan $1 \mathrm{~s} / \mathrm{d} 10$ $\mathrm{K} 11 \mathrm{~s} / \mathrm{d}$ K20 = Perlakuan tanah Kebar dan 0,165 g NPK, untuk ulangan $1 \mathrm{~s} / \mathrm{d} 10$ A21 $\mathrm{s} / \mathrm{d}$ A30 = Perlakuan tanah Amban dan 0,330 g NPK, untuk ulangan $1 \mathrm{~s} / \mathrm{d} 10$ $\mathrm{K} 21 \mathrm{~s} / \mathrm{d}$ K30 = Perlakuan tanah Kebar dan 0,330 g NPK, untuk ulangan $1 \mathrm{~s} / \mathrm{d} 10$

\section{Pelaksanaan Penelitian}

Penelitian akan dilakukan dalam beberapa tahap yaitu:

a) Tahap Pengambilan Tanah dan Bibit Rumput; Tanah yang digunakan untuk penelitian ini berasal dari 2 (dua) lokasi yaitu tanah berasal dari Kampung Jandurau, Distrik Kebar dan tanah berasal dari Kebun Percobaan Manggoapi Amban milik Fakultas Pertanian dan Teknologi Pertanian Univarsitas Papua (Fapertek-Unipa). Contoh tanah penelitian dikering anginkan selama kurang lebih 1 minggu, kemudian ditimbang sebanyak $1 \mathrm{~kg}$ untuk keperluan analisis tanah, yang meliputi $\mathrm{pH}$ tanah, kadar bahan organik (BO), dan tekstur tanah. Bibit rumput yang digunakan adalah rumput Ischaemum $s p$ yang berupa sobekan akar (pols) diperoleh dari areal padang penggembalaan alam kampung Jandurau, Distrik Kebar.

b) Tahap Pengolahan Tanah dan Penyiapan Polibag/Pot; Sebelum dilakukan penanaman rumput Iscahaemum sp dalam polibag/pot percobaan, untuk menjamin agar tanaman dapat tumbuh dengan baik maka terlebih dahulu tanah dibersihkan dari sisa tanaman dan akar, serta kotoran. Selanjunya diayak dan dimasukkan dalam polibag sebanyak $1 \mathrm{~kg}$ tanah kering. Polibag yang digunakan adalah sebanyak 6o (enam puluh) buah yang berukuran panjang $20 \mathrm{~cm}$ dan lebar $9 \mathrm{~cm}$. Jumlah masingmasing percobaan 30 polibag untuk tanah asal Kebar dan 30 polibag untuk tanah asal Amban. Setiap polibag berisi 3 batang pols/bibit rumput. Jumlah pols yang dibutuhkan menurut perlakuan asal tanah dan pupuk NPK adalah 60 pols (180 batang).

c) Tahap Penanaman Bibit, Pemupukan dan Penyiraman; Rumput Ischaemum sp yang diambil dari Kebar dibiarkan selama 1 (satu) hari, kemudian penanaman dilakukan. Pols rumput terlebih dahulu dipangkas dan dibersihkan dari tumbuhan pengganggu. Dicabut dengan hati-hati dengan tanah disekitar akar dipertahankan untuk menjamin pertumbuhan rumput. Dipilih 3 batang yang relatif sama sebagai bahan penanaman (pols). Penanaman rumput Ischaemum sp masing-masing 30 pols untuk tanah asal Amban, dan 30 pols lainnya untuk tanah asal Kebar. Pupuk NPK diberikan dengan cara di tugal pada 2 (dua) sisi tanaman dengan kedalaman sekitar $2-3 \mathrm{~cm}$. Pemupukan dilakukan sekitar 4 (empat) minggu, setelah pemangkasan untuk menyeragamkan pertumbuhan rumput. Penyiraman dilakukan secara rutin dengan memperhatikan keadaan tanah dan kondisi pertumbuhan tanaman.

d) Tahap Adaptasi; Setiap batang disemaikan terlebih dahulu dalam polibag/pot kapasitas 1 (satu) $\mathrm{kg}$, setelah tanaman tumbuh pada umur sekitar empat minggu dilakukan pemotongan 
atau pemangkasan rumput tersebut untuk memulai penelitian (masa adaptasi).

e) Tahap Perlakuan Pupuk; Pupuk yang digunakan pada penelitian ini adalah pupuk NPK $(15 \mathrm{~N}$ : $15 \mathrm{P}$ : ${ }_{15} \mathrm{~K}$ ) berbentuk pelet atau butiran dan berwarna hijau kebiruan yang berasal dari Toko Pupuk Pertanian di Wosi Manokwari. Pupuk N, P dan $\mathrm{K}$ mengandung $15 \% \mathrm{~N}, 15 \% \mathrm{P}$, dan $15 \% \mathrm{~K}$. Dosis anjuran yang digunakan adalah $100 \mathrm{~kg} \mathrm{~N} / 50$ $\mathrm{kg} \mathrm{P} / 50 \mathrm{~kg} \mathrm{~K}$ per ha, sehingga pada penelitian ini digunakan 2 (dua) standar pupuk $\mathrm{N}$ yaitu dosis $100 \mathrm{~kg} \mathrm{~N}$ dan $50 \mathrm{~kg} \mathrm{~N}$ per ha.

f) Tahap Pengamatan; Untuk pengamatan dilakukan melalui pengukuran tinggi tanaman yang dilakukan setiap minggu. Perhitungan waktu pengukuran dimulai sejak terbentuknya daun secara lengkap (terdapat lembaran daun dan pelepah daun), selanjutnya dilakukan pengukuran setiap minggu. Pemanenan tanaman dilakukan saat rumput Ischaemum $s p$ sudah berbunga sekitar 10\% dari populasi tanamanp ada pot percobaan yang mendapat perlakuan yang sama. Tanaman sesuai perlakuan dalam setiap pot dipangkas sekitar $5 \mathrm{~cm}$ dari permukaan tanah dalam pot, selanjutnya dilakukan pengukuran panjang daun, lebar daun, panjang ruas, dan diameter ruas.

\section{Variabel Penelitian}

Variabel yang diamati pada penelitian tahap pertama tentang karakteristik dan morfologi rumput Ischaemum sp, masing-masing:

a) Tinggi Tanaman $(\mathrm{cm})$; Pengukuran tinggi tanaman dilakukan mulai dari permukaan tanah hingga pucuk daun terpanjang/tertinggi pada setiap pot percobaan setiap minggu.

b) Jumlah Anakan (Tanaman); Yang dimaksud dengan anakan dalam penelitian ini adalah tanaman baru yang tumbuh/keluar ke atas permukaan tanah pada setiap pot percobaan setiap minggu.

c) Jumlah Daun; Sedangkan jumlah daun dihitung hanya daun lengkap yang masih hijauan pada setiap pot percobaan setiap minggu.

d) Panjang Daun (cm); Panjang daun terpanjang, diukur mulai pangkal daun hingga ujung daun.

e) Lebar Daun (cm); Lebar daun diukur pada daun terpanjang tepat pada bagian tengah.

f) Panjang Ruas (cm); Panjang antara buku pertama dengan buku berikutnya. Bila lebih dari 1 ruas, yang digunakan adalah ruas terpanjang.

g) Diameter Ruas; Diameter ruas diukur pada pertengahan antara buku pertama dengan buku berikutnya.

\section{Analisis Data}

Data yang diperoleh dianalisis varians (Anova) dari rancangan acak lengkap (RAL) pola faktorial dengan 2 perlakuan asal tanah sebagai faktor pertama dan 3 macam dosis pupuk NP K sebagai faktor kedua, dengan 10 ulangan (RAL $2 \times 3 \times 10$ ). Perlakuan yang berpengaruh signifikan dilakukan uji Beda Nyata Jujur (BNJ) menurut Hanafiah (1990).

\section{HASIL DAN PEMBAHASAN}

Pertumbuhan rumput Ischaemum sp secara umum cukup baik. Hal ini ditunjang dengan kondisi iklim selama penelitian berlangsung. Hasil analisis tanah menunjukkan bahwa tanah Amban memiliki kriteria $\mathrm{pH}$ netral $(6,89 \%)$, kriteria carbon organik (C-organik) sangat rendah (0,517\%), persentase bahan organik (BO) o,891\%, tekstur tanah lempung liat berpasir, sedangkan tanah Kebar kriteria $\mathrm{pH}$ masam (4,55\%), kriteria C-Org sangat rendah (o,651\%), persentase BO 1,122\%, tekstur tanah lempung liat berpasir.

\section{Tinggi Tanaman}

Hasil penelitian ini menunjukkan bahwa seluruh level dosis pupuk NPK pada tanah asal Amban dan Kebar, mulai minggu ke-2 setelah pemupukan hingga minggu ke-6 tanaman rumput Ischaemum $s p$ mengalami pertumbuhan yang linier. Hasil analisis varians terlihat bahwa pengaruh dosis pupuk NPK dengan berbagai level pada tanah asal Amban dan Kebar terhadap tinggi tanaman rumput Ischaemum $s p$ dari 2 MSP hingga 6 MSP tidak memberikan pengaruh yang nyata $(\mathrm{P}>0,05)$, hal ini berarti bahwa pertumbuhan tinggi tanaman, baik yang diberikan pupuk 0,165 NPK dan 0,330 NPK serta yang tidak diberikan pupuk (oNPK) mempunyai tingkat pertumbuhan yang relatif sama.

Secara lengkap pertumbuhan ditinjau dari ratarata tinggi tanaman dan selisih pertambahan tinggi tanaman sebagai indikator laju pertumbuhan tanaman rumput Ischaemum sp disajikan pada Gambar 1.

Pada gambar diatas tampak bahwa rata-rata tinggi tanaman setiap minggu setelah pemupukan pada tanah asal Amban dan Kebar relatif sama pada level dosis o NPK (kontrol), 0,165 NPK dan 0,330 NPK. Pada umur 6 minggu tinggi tanaman dapat mencapai 48,20 cm (o,330 NPK) dan 46,90 cm (0,165 NPK) pada tanah asal Kebar. Rata-rata tinggi tanaman hasil penelitian ini masih lebih rendah dibandingkan dengan hasil penelitian Muhakka et al. (2011), tentang respon pertumbuhan rumput rawa (Ischaemum rugosum) dengan pemberian sulfur di lahan kering diperoleh hasil rata-rata tinggi tanaman rumput rawa defoliasi umur 40 hari sebanyak 2 periode pada 


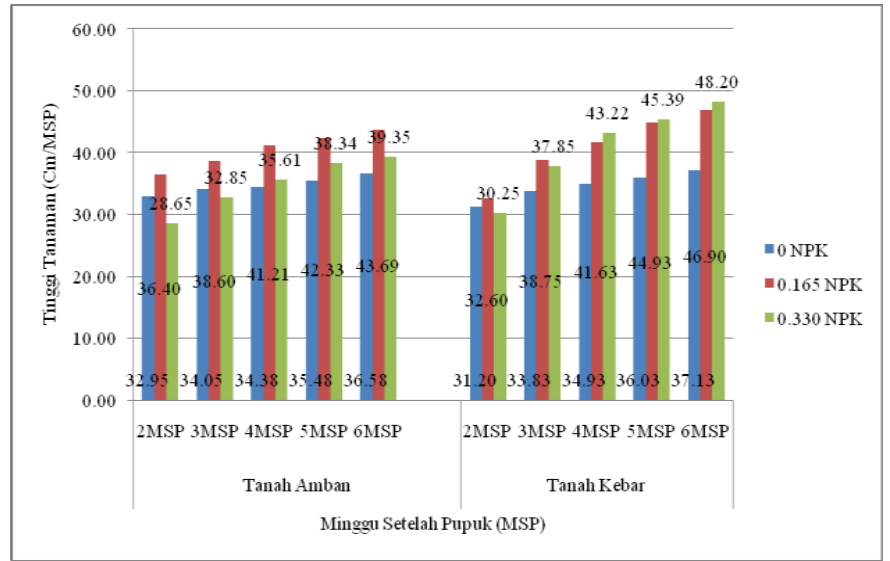

Gambar 1. Grafik Rata-rata Tinggi dan Selisih Pertambahan Tinggi Tanaman Rumput Ischaemum sp

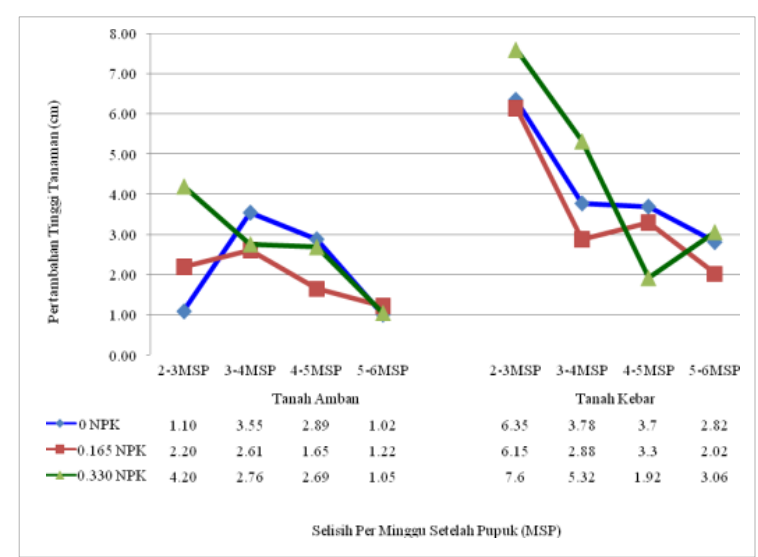

Gambar 2.

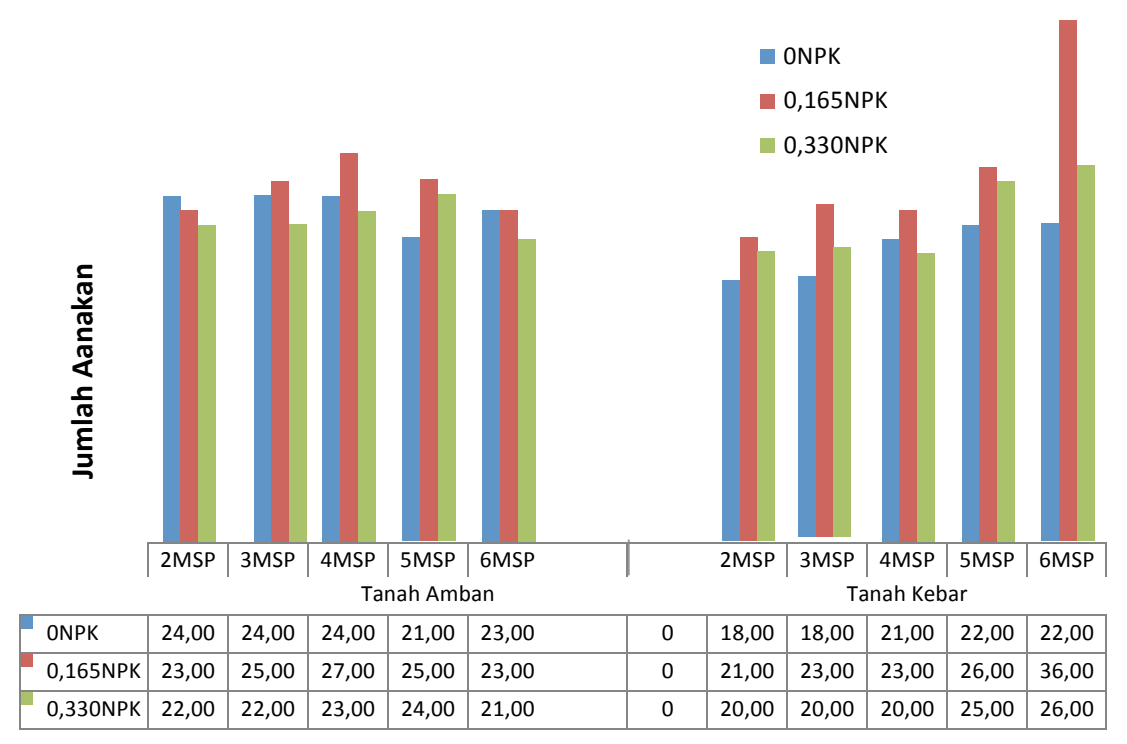

Waktu Pengamatan Perminggu

Gambar 3. Grafik Rataan Jumlah Anakan

beberapa dosis sulfur (S) berbeda yaitu mencapai 153 cm pada perlakuan kontrol (tanpa sulfur), $127,17 \mathrm{~cm}$ (30 kg S/ha), 155,00 cm (70 kg S/ha) dan 128,33 cm (150 kg S/ha). Sedangkan laju pertumbuhan rumput Ischaemum sp pada tanah asal Amban lebih rendah dibanding tanah asal Kebar. Hal ini diduga karena pols yang digunakan berasal dari dataran Kebar, sehinga memiliki daya adaptasi yang lebih cepat dibanding tanah asal Amban. Hal ini juga tampak pada selisih pertambahan tinggi tanaman 2-3MSP pada tanah Amban perlakuan o NPK (kontrol) dan 0,165 NPK baru mencapai pertumbuhan tertinggi pada 3-4MSP, sedangkan perlakuan 0,330 NPK pada minggu ke 2-3MSP hal ini diduga karena level pupuk NPK yang lebih tinggi sehingga merangsang pertumbuhan lebih cepat. Sebaliknya pada tanah asal Kebar semua perlakuan level dosis pupuk NPK mencapai pertumbuhan maksimal pada selisih 2-3MSP, namun pada selisih 4-5MSP terjadi sedikit peningkatan tinggi tanaman pada perlakuan o NPK (kontrol) dan 0,165 NPK, serta perlakuan 0,330 NPK pada 5 -6MSP.

\section{Jumlah Anakan}

Rata-rata jumlah anakan dari 2 minggu setelah pupuk (MSP) hingga 6 minggu setelah pupuk pada tanah asal Amban dan Kebar dengan perlakuan level dosis pupuk NPK yang berbeda disajikan pada Gambar 3.

Hasil analisis ragam menunjukkan bahwa pemberian perlakuan pupuk NPK berpengaruh tidak nyata $(\mathrm{P}>0,05)$ terhadap jumlah anakan masingmasing perlakuan. Bosawer (2004), menyatakan bahwa kandungan $\mathrm{N}$ dalam tanah tergolong sedang, sehingga pupuk urea yang diberikan dalam penelitian ini tidak memberikan pengaruh yang nyata. Pada Gambar 3 diketahui bahwa rataan jumlah anakan pada 6 MSP pada tanah asal Kebar mengalami 


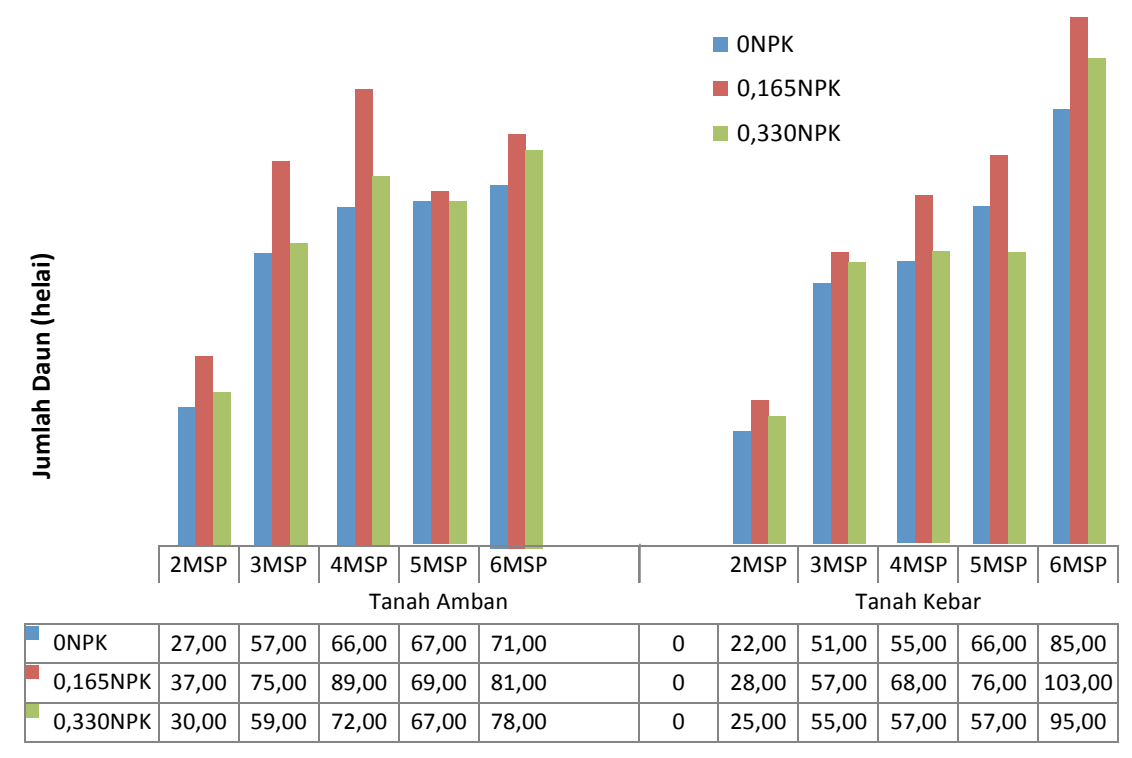

Waktu Pengamatan Perminggu

Gambar 4. Grafik Rata-rata Jumlah Daun (Helai)

peningkatan yaitu pada perlakuan dosis pupuk 0,165 NPK sebesar 36,00 anakan, sedangkan pada tanah asal Amban mengalami peningkatan pada 4 MSP yaitu pada perlakuan dosis pupuk 0,165 NPK sebesar 27,00 anakan. Hal ini diduga karena pols yang digunakan berasal dari dataran Kebar, sehinga memiliki daya adaptasi yang lebih cepat dibanding tanah asal Amban. Menurut Muhakka et al. (2011), tentang respon pertumbuhan rumput rawa (Ischaemum rugosum) dengan pemberian sulfur di lahan kering diperoleh hasil rata-rata jumlah anakan (per rumpun) tanaman rumput rawa pada defoliasi umur 40 hari sebanyak 2 periode pada beberapa dosis sulfur (S) berbeda yaitu 13,00 pada perlakuan kontrol (tanpa sulfur), 12,33 cm (30 kg S/ha), 8,33 cm (70 kg S/ha) dan 14,00 cm (150 kg S/ha).

\section{Jumlah Daun}

Hasil penelitian ini menunjukkan rata-rata jumlah daundari 2 minggu setelah pupuk (MSP) hingga 6 minggu setelah pupuk pada tanah asal Amban dan Kebar dengan perlakuan level dosis pupuk NPK yang berbeda disajikan pada Gambar 4. Pada gambar 4 diketahui bahwa rataan jumlah daun pada 6 MSP pada tanah asal Kebar mengalami peningkatan yaitu pada perlakuan dosis pupuk 0,165 NPK sebesar 103,00 helai, sedangkan pada tanah asal Amban mengalami peningkatan pada 4 MSP yaitu pada perlakuan dosis pupuk 0,165 NPK sebesar 89,00 helai. Hal ini diduga karena pols yang digunakan berasal dari dataran Kebar, sehinga memiliki daya adaptasi yang lebih cepat dibanding tanah asal Amban. Menurut Muhakka, et al (2011), tentang respon pertumbuhan rumput rawa (Ischaemum rugosum) dengan pemberian sulfur di lahan kering diperoleh hasil rata-rata jumlah anakan (per rumpun) tanaman rumput rawa pada defoliasi umur 40 hari sebanyak 2 periode pada beberapa dosis sulfur (S) berbeda yaitu 13,00 pada perlakuan kontrol (tanpa sulfur), 12,33 cm (30 kg S/ha), 8,33 cm (70 kg S/ ha) dan 14,00 cm (150 kg S/ha).

\section{Panjang dan Lebar Daun}

Pengukuran panjang daun dilalukan saat panen 6 MSP. Rata-rata panjang daun pada 2 MSP hingga 6 MSP mempunyai kisaran tertinggi pada tanah Kebar yaitu pada perlakuan dosis pupuk o NPK sebesar 269,00 cm dan pada dosis pupuk 0,330 NPK sebesar 268,50 cm, sedangkan pada tanah Amban memiliki rataan panjang daun pada perlakuan dosis pupuk 0,165 NPK sebesar 234,00 cm. Rata-rata lebar daun pada 2 MSP hingga 6 MSP mempunyai kisaran tertinggi pada perlakuan dosis pupuk o NPK pada tanah asal Kebar yaitu sebesar $15,90 \mathrm{~cm}$ dan pada tanah Amban memiliki lebar daun pada dosis pupuk 0,165 NPK sebesar $13,80 \mathrm{~cm}$. Hasil analisis ragam perlakuan tidak berpengaruh nyata $(\mathrm{P}>0,05)$ terhadap panjang dan lebar daun. Panjang daun pada perlakuan dosis pupuk 0,165 NPK dalam penelitian ini lebih tinggi bila dibandingkan dengan hasil penelitian Anwar dan Kushartono (2000), dimana jumlah panjang daun sebesar 101,99 $\mathrm{cm}$.

\section{Panjang Ruas}

Pengukuran panjang dan diameter batang dilakukan saat panen pertama. panjang ruas sesuai 
perlakuan dosis pupuk pada tanah asal Amban dan Tanah Kebar pada minggu keenam memiliki perbedaan. Pada minggu keenan antara perlakuan dosis pupuk 0,330 NPK pada tanah Kebar mengalami peningkatan sebesar $30,10 \mathrm{~cm}$, sedangkan pada perlakuan dosis pupuk o NPK pada tanah asal Amban sebesar $15,60 \mathrm{~cm}$. Hal ini diduga karena pols yang digunakan berasal dari dataran Kebar, sehinga memiliki daya adaptasi yang lebih cepat dibanding tanah asal Amban. Hasil analisis ragam perlakuan tidak berpengaruh nyata $(\mathrm{P}>0,05)$, terhadap panjang ruas. Hal ini disebabkan oleh umur hijauan yang semakin menua menyebabkan peningkatan kandungan serat kasar sementara kandungan air, protein, karbohidrat menurun sehingga ukuran diameter batang menjadi lebih kecil (Holmes, 1980). Siregar (1981) menyatakan bahwa produktivitas pada tanaman tropik apabila diberikan pemupukan $\mathrm{N}$ maka hasilnya akan meningkat namun apabila berlebihan akan menurunkan produksi.

\section{Diameter Batang}

Pengukuran diameter batang dilakukan saat panen minggu ke 6. Hasil analisis ragam perlakuan asal tanah dan dosis pupuk NPK tidak berpengaruh nyata $(\mathrm{P}>0,05)$ terhadap diameter batang. Gambar 8 menunjukkan bahwa rata-rata diameter batang sesuai perlakuan dosis pupuk NPK pada tanah asal Amban dan tanah Kebar pada minggu keenam memiliki perbedaan. Rata-rata diameter batang minggu keenan antara perlakuan dosis pupuk 0,165 NPK pada tanah Kebar mengalami peningkatan sebesar 2,75 cm, sedangkan tanah asal Amban pada perlakuan dosis pupuk 0,165 NPK sebesar 2,45 cm Menurut Siregar, 1981, bahwa produktifitas pada tanaman tropik apabila diberikan pemupukan $\mathrm{N}$ maka hasilnya akan meningkat namun apabila berlebihan akan menurunkan produksi.

\section{KESIMPULAN}

\section{Berdasarkan hasil penelitian dapat di simpul- kan bahwa:}

1. Pemberian perlakuan tanah asal Amban dan Kebar dengan dosisi pupuk o NPK, 0,165 NPK, dan 0,330 NPK tidak memberikan pengaruh yang signifikan terdahap pertumbuhan tinggi tanaman, jumlah anakan dan jumlah daun serta karakteristik daun (panjang dan lebar daun), batang (panjang ruas dan diameter batang).
2. Rata-rata pertumbuhan tinggi dan laju pertumbuhan, serta jumlah anakan dan jumlah daun tanaman rumput Ischaemum sp pada tanah Kebar lebih tinggi dibandingkan tanah asal Amban.

3. Karakteristik daun dan batang rumput Ischaemum $s p$ pada 2MSP hingga 6MSP ukuran maksimal panjang daun $36,2 \mathrm{~cm}$, lebar daun 1,7 , panjang ruas $7,5 \mathrm{~cm}$ dan diameter batang $0,3 \mathrm{~mm}$.

\section{DAFTAR PUSTAKA}

Anwar, M. dan B. Kushartono. 2000. Pengaruh Perbedaan Penggunaan Pupuk terhadap Produksi Rumput Raja (Pennisetum purpureophoides) di Lapangan Percobaan Ciawi. Prosiding Temu Teknis Fungsional Non Penelitian. Pusat Penelitian dan Pengembangan Peternakan. Badan Penelitian dan Pengembangan Pertanian. Departemen Pertanian, Bogor. 10 (4): 224-229.

Bosawer, A. L. 2004. Pengaruh Dosis Pupuk NPK terhadap pertumbuhan dan produksi Rumput Irian (Sorgum sp) pada Defoliasi Pertama. Skripsi Sarjana Peternakan. Fakultas Peternakan Perikanan dan Ilmu Kelautan Universitas Papua, Manokwari (tidak diterbitkan).

Hanafiah, K. A. 1990. Perancangan Percobaan (Experimental Design) Teori dan Aplikasi. Fakultas Pertanian Universitas Sriwijaya. Palembang.

Holmes, W. 1980. Grass Its Production and Utilization. Blackwell Scientific Publications. Austlaia.

Muhakka, H., Muchlison, A. Indra, M., Ali dan G. Muslim. 2011. Respon Pertumbuhan Rumput Rawa (Ischaemum rugosum) Dengan Pemberian Sulfur Di Lahan Kering. Makalah Seminar Nasional Teknologi Peternakan dan Veteriner. Bogor.

Sajimin, I. P. Kompiang, Supriyati dan Suratmini. 2001. Penggunaan Biofertilizer untuk Peningkatan Produkstifitas Hijauan Pakan Rumput Gajah (Pennisetum purpureum cv Afrika) pada Lahan Marjinal di Subang Jawa Barat. Media Peternakan.

Sirait, J., N. D. Purwantari dan K. Simanihuruk. 2005. Produksi dan Serapan Nitrogen Rumput dan Naungan dan pemupukan yang Berbeda. Jurnal Ilmu Ternak dan Veteriner.

Siregar, H. 1981. Budidaya Tanaman Padi di Indonesia. Sastra Hudaya. Jakarta. 